\title{
Pengaruh Kompres Hangat terhadap Nyeri Punggung Ibu Hamil Trimester III di Puskesmas Sekernan Ilir Tahun 2020
}

\author{
Yuli Suryanti $^{1}$, Dewi Nopiska Lilis ${ }^{2}$, Harpikriati $^{3}$ \\ ${ }^{1-3}$ Politeknik kesehatan kemenkes Jambi Jurusan kebidan \\ Email:herinawati@yahoo.com
}

Submitted : 21/07/2020

Accepted: 06/01/2021

Published: 06/03/2021

\begin{abstract}
Introduction Back pain is the most common complaint with a prevalence rate of $49 \%$. Back pain that is not immediately treated, can cause long-term back pain, increase the tendency of postpartum back pain and chronic back pain that will be more difficult to treat or cure, that is, when the pain spreads to the pelvic region which causes difficulty walking and thus requires crutches or assistive devices. other way. PURPOSEQuantitative research with quasi-experimental design with one group pretest-posttest to determine the effect of Warm Compresses on Back Pain of Trimester III Pregnant Women in SekernanIlir Health Center in 2020. Methodsthe population is all Trimester III pregnant women in the work area of SekernanIlir Health Center up to January 2020 which totaling 296 people. Samples were 30 respondents. This research was conducted from January to March 2020. ResultsData analysis was carried out univariate and bivariate. The result of univariate analysis before giving a warm compress is moderate pain. The results of bivariate analysis showed that there was an effect of warm compresses on the level of back pain in third trimester pregnant women and p-value $=0.000(p<0.05)$. conclusionit is expected that the Puskesmas will provide knowledge to pregnant women about ways to reduce back pain in third trimester pregnant women, in addition to pharmacological treatment, it can also be done with nonpharmacological treatment, namely warm compresses
\end{abstract}

Keywords: back pain, third trimester pregnant women, warm compresses

\begin{abstract}
Abstrak
Nyeri punggung merupakan keluhan yang paling banyak dijumpai dengan angka prevalensi mencapai $49 \%$. Nyeri punggung yang segera tidak diatasi, bisa mengakibatkan nyeri punggung jangka panjang, meningkatkan kecenderungan nyeri punggung pasca partum dan nyeri punggung kronis yang akan lebih sulit untuk diobati yaitu ketika nyeri sampai menyebar kedaerah pelvis yang menyebabkan kesulitan berjalan sehingga memerlukan kruk ataupun alat bantu jalan lainnya. Penelitian kuantitatif dengan desain quasi eksperimen dengan one group pretest-posttest untuk mengetahui Pengaruh Kompres Hangat Terhadap Nyeri Punggung Ibu Hamil Trimester III Di Puskesmas Sekernan Ilir Tahun 2020. Populasi adalah seluruh ibu hamil Trimester III di wilayah kerja Puskemas Sekernan Ilir sampai dengan bulan Januari 2020 yang berjumlah 296 orang. Sampel sebanyak 30responden. Penelitian ini dilakukan pada Januari s/d Maret 2020. Analisis data dilakukan secara univariat dan bivariat. Hasil analisis univariat sebelum diberikan kompres hangat rata-rata derajat nyeri adalah 5,857 dan sesudah diberikan kompres hangat rata-rata derajat nyeri berkurang menjadi 4,513. Hasil analisis bivariat didapatkan ada pengaruh kompres hangat terhadap tingkat nyeri punggung ibu hamil trimester III dan diperoleh $p$-value $=0.000(\mathrm{p}<0.05)$. Diharapkan Puskesmas memberikan cara pada ibu hamil tentang bagaimana mengurangi nyeri punggung ibu hamil trimester III, yaitu selain dengan pengobatan non farmakologi yaitu kompres hangat.
\end{abstract}

Kata kunci: kompres hangat, nyeri punggung, wanita hamil trimester III

\section{PENDAHULUAN}

Kehamilan sebagai suatu kondisi dimana seorang perempuan sedang mengandung fetus didalam rahimnya selama sembilan bulan atau selama fetus berada didalam kandungan ibu. Selama masa kehamilan ibu hamil mengalami perubahan fisik dan psikologis yang dapat menimbulkan ketidaknyamanan terutama pada trimester III yaitu insomnia, sering 
berkemih, tekanan dan ketidaknyamanan pada perinium, nyeri punggung bawah, konstipasi, varises, mudah lelah, kram kaki, dan oedema pergelangan kaki (WHO, 2014).

Di Indonesia terdapat 5.298.285 orang ibu hamil, untuk wilayah kota Semarang 53.734 orang. Sedangkan diwilayah Provinsi Jawa Tengah jumlahnya ada 314.492 orang ibu hamil yang mengalami nyeri punggung (Profil Data Kesehatan Indonesia, 2015).

Nyeri punggung di Indonesia lebih sering di jumpai pada ibu hamil dan pada golongan usia 40 tahun. Secara keseluruhan nyeri punggung merupakan keluhan yang paling banyak dijumpai dengan angka prevalensi mencapai 49\%, 80-90\% dari ibu hamil yang mengalami nyeri punggung menyatakan tidak melakukan usaha apapun untuk mengatasi timbulnya gejala tersebut, dengan kata lain hanya sekitar 10-20\% dari mereka yang melakukan perawatan medis ke tenaga kesehatan (Kreshnanda, 2016).

Nyeri punggung yang segera tidak diatasi, bisa mengakibatkan nyeri punggung jangka panjang, meningkatkan kecenderungan nyeri punggung pasca partum dan nyeri punggung kronis yang akan lebih sulit untuk diobati atau disembuhkan, yaitu ketika nyeri sampai menyebar kedaerah pelvis yang menyebabkan kesulitan berjalan sehingga memerlukan kruk ataupun alat bantu jalan lainnya. Nyeri punggung bawah dapat menimbulkan dampak negatif pada kualitas hidup ibu hamil karena terganggunya aktifitas fisik sehari-hari misalnya akan kesulitan menjalankan aktivitas seperti berdiri setelah duduk, berpindah dari tempat tidur, duduk terlalu lama, berdiri terlalu lama, membuka baju dan melepaskan baju, maupun mengangkat dan memindahkan benda-benda sekitar (Luthfiah, 2016:149).

Metode non farmakologis yang dapat mengurangi nyeri yaitu dengan kompres hangat yang dapat memberikan manfaat seperti memberikan rasa nyaman, mengurangi atau mencegah terjadinya spasme otot dan memberikan rasa hangat (Ardiana, 2016:3).

Berdasarkan penelitian yang dilakukan oleh Tri (2018) di Klinik Pelita Hati Banguntapan bantul didapatkan ada perbedaan yang signifikan antara intensitas nyeri sebelum dan sesudah diberikan kompres hangat. Penurunan skala nyeri setelah diberikan kompres hangat adalah 3,30 yaitu sebelum diberikan rata-rata inensitas nyeri yaitu 7,35 (Nyeri berat) dan sesudah di berikan kompres hangat adalah 4,05 (Nyeri Sedang). Sehingga kompres hangat yang dilakukan pada ibu hamil trimester III berpengaruhmenurunkan intensitas nyeri punggung yang dirasakan ibu.

Penelitian ini juga sejalan dengan Aulia, dkk (2018) yang menyatakan bahwa terdapat penurunan nyeri punggung pada ibu hamil Trimester III yang diberikan tindakan kompres hangat dengan rata-rata intensitas nyeri punggung sebelum diberikan kompres hangat adalah 5.035 (nyeri sedang) dan setelah diberikan kompres hangat menjadi 1.607 (nyeri ringan).

Kabupaten Muaro Jambi jumlah ibu hamil tahun 2018 berjumlah 10.316 dengan capaian K4 sebanyak 9.437 ( 91,48 \%) dan tahun 2019 jumlah ibu hamil sebanyak 10.825 dengan capaian K4 7.221 (66,71\%) sampai dengan september 2019 (Sumber Laporan KIA Dinkes Kabupaten Muaro Jambi 2019). Sementara jumlah ibu hamil di wilayah kerja Puskesmas Sekernan Ilir jumlah pada tahun 2018 berjumlah 258 dengan capaian K4 sebanyak $257(99,61 \%)$ dan tahun 2019 jumlah ibu hamil sebanyak 270 ibu dengan capaian K4 sampai dengan september 2019 sebanyak 230 (75,19\%) (Laporan Puskesmas Sekernan Ilir, 2019).

Hasil survey pendahuluan yang dilakukan di Puskesmas Sekernan Ilir terhadap 25 ibuhamil TM III yang diwawancarai, terdapat 20 ibuhamil tercatat 
nyeri punggung sering berulang-ulang terutama pada bagian punggung bawah. Sedangkan selebihnya ibuhamil lainnya menyatakan bahwa pernah juga mengalami nyeri punggung bagian bawah tetapi tidak mengganggu aktivitas ibu, nyeri punggung sering dirasakan ibu hamil pada malam hari.

Ibu hamil yang mengalami nyeri punggung yang berulang sebanyak $20 \mathrm{ibu}$ hamil, dan 5 ibu hamil yang pernah mengalami nyeri tapi tidak mengganggu aktivitas ibu. Sedangkan untuk 20 ibu hamil yang mengalami nyeri punggung dan mengganggu aktivitasnya mengatakan bahwa terapi yang digunakanuntukmenghilangkannyeripadapu nggungibuhamil adalah 5 orang menggunakan teknik pijat, 3 orang menggunakan minyakkayuputih dan minyak aromaterapi yang dioleskan pada bagian nyeri, 3 orang menggunakan teknik mobilisasi dan 9 orang menggunakan kompres hangat yang dapatmembantumenguranginyeri.

Berdasarkan latar belakang diatas penulis akan melakukan penelitian tentang pengaruh kompres hangat terhadapnyeri punggungibuhamil trimester III di Puskesmas Sekernan Ilir Tahun 2020.

\section{METODE PENELITIAN}

Penelitian ini adalah penelitian kuantitatif dengan desain quasi eksperimen dengan bentuk rancangan one group pretest-posttest yaitu mengungkapkan hubungan sebab akibat dengan cara melibatkan suatu kelompok subjek, dimana kelompok subjek diobservasi sebelum dilakukan intervensi, kemudian observasi lagi setelah intervensi. Populasi penelitian ini adalah seluruh ibu hamil TM III di wilayah kerja Puskesmas Sekernan Ilir sampai dengan bulan Januari 2020 yang berjumlah 296 orang. Sampel dalam penelitian ini adalah ibuhamilsebanyak 30responden. Penelitian ini dilakukan di Puskesmas Sekernan Ilir dan dilakukan pada Januari s/d Maret 2020. Teknik pengambilan sampel dilakukan dengan cara purposive sampling. Pengumpulan data dilakukan dengan cara peneliti menganalisis tingkat nyeri punggung ibu hamil lalu kemudian di observasi selama 15 menit dengan diberikan intervensi kompres hangat, setelah itu tingkat nyeri di analisis kembali. Analisis data penelitian ini dilakukan secara univariat dan bivariat dengan menggunakan uji sample t test.

\section{HASIL DAN PEMBAHASAN}

1. Gambaran tingkat nyeri punggung ibu hamil trimester III sebelum diberikan kompres hangat di Puskesmas Sekernan Ilir tahun 2020. Berdasarkan hasil penelitian Gambaran tingkat nyeri punggung ibu hamil trimester III sebelum diberikan kompres hangat dapat dilihat pada tabel 5.1 berikut :

Tabel 1. Distribusi Tingkat Nyeri Punggung Ibu Hamil SebelumD iberikan Kompres Hangat di Puskesmas Sekernan Ilir Tahun 2020

\begin{tabular}{|c|c|c|c|c|c|c|}
\hline \multirow[b]{2}{*}{$\begin{array}{l}\text { NyeriPunggun } \\
\mathrm{g}\end{array}$} & \multicolumn{2}{|c|}{ Sebelum } & \multirow[b]{2}{*}{$\begin{array}{c}\text { Mea } \\
\mathrm{n}\end{array}$} & \multirow[b]{2}{*}{$\begin{array}{l}\mathrm{S} \\
\mathrm{D}\end{array}$} & \multirow{2}{*}{$\begin{array}{c}\text { Min } \\
- \\
\text { Ma } \\
\text { k }\end{array}$} & \multirow{2}{*}{$\begin{array}{c}95 \% \\
\text { CI }\end{array}$} \\
\hline & $f$ & $\%$ & & & & \\
\hline Ringan & 0 & 0.0 & & & & 5,63 \\
\hline Sedang & $\begin{array}{l}2 \\
8\end{array}$ & 93,3 & 5,9 & 0 , & $4,7-$ & $\begin{array}{c}7- \\
6,07\end{array}$ \\
\hline Berat & 2 & 6,7 & & & & 6 \\
\hline Jumlah & $\begin{array}{l}3 \\
0\end{array}$ & $\begin{array}{c}100 . \\
0\end{array}$ & & & & \\
\hline
\end{tabular}

Hasil analisis dapatdiketahui bahwa sebelum melakukan kompres hangat sebagian besar responden mengalami nyeri punggung yang sedang yaitu sebanyak 28 responden $(93,3 \%)$ dengan skor rata-rata nyeri punggung yang dialami oleh ibu hamil adalah 5,857 (nyeri sedang), dengan standar deviasi 0,5882. Derajat nyeri terendah adalah 4,7 (nyeri sedang) dan 
derajat nyeri tertinggi 7 (nyeri berat). Dari hasil estimasi interval dapat disimpulkan bahwa $95 \%$ diyakini derajat nyeri sebelum dilakukan kompres hangat adalah diantara 5,637 (nyeri sedang) - 5,607 (nyeri sedang).

2. Gambaran tingkat nyeri punggung ibu hamil trimester III sesudah diberikan kompres hangat di Puskesmas Sekernan Ilir tahun 2020.

Berdasarkan hasil penelitian Gambaran tingkat nyeri punggung ibu hamil trimester III sesudah diberikan kompres hangat dapat dilihat pada tabel 5.2 berikut :

Tabel 2. Distribusi Tingkat Nyeri Punggung Ibu Hamil Sesudah Diberikan Kompres Hangat di Puskesmas Sekernan Ilir Tahun 2020

\begin{tabular}{|c|c|c|c|c|c|c|}
\hline \multirow{2}{*}{$\begin{array}{c}\text { Nyeri } \\
\text { Punggung }\end{array}$} & \multicolumn{2}{|c|}{ Sesudah } & \multirow[b]{2}{*}{ Mean } & \multirow[b]{2}{*}{ SD } & \multirow{2}{*}{$\begin{array}{c}\text { Min } \\
- \\
\text { Mak }\end{array}$} & \multirow{2}{*}{$95 \% \mathrm{CI}$} \\
\hline & $f$ & $\%$ & & & & \\
\hline Ringan & 4 & 13,3 & \multirow{3}{*}{4,5} & \multirow{3}{*}{0,6} & & 4,278 \\
\hline Sedang & 26 & 86,7 & & & $3,3-$ & \\
\hline Berat & 0 & 0,0 & & & 5,7 & 2,749 \\
\hline Jumlah & 30 & 100.0 & & & & \\
\hline
\end{tabular}

Hasil analisis dapat diketahui bahwa sesudah melakukan kompres hangat sebagian besar responden mengalami nyeri punggung yang sedang yaitu sebanyak 26 responden $(86,7 \%)$ dan yang mengalami nyeri punggung yang berat sudah tidak ada lagi $0 \quad(0 \%)$ dengan skor rata-rata nyeri punggung yang dialami oleh ibu hamil adalah 4,513 (nyeri sedang), dengan standar deviasi 0,6301. Derajat nyeri terendah adalah 3,3 (nyeri ringan) dan derajat nyeri tertinggi 5,7 (nyeri sedang). Dari hasil estimasi interval dapat disimpulkan bahwa 95\% diyakini derajat sesudah dilakukan kompres hangat adalah diantara 4,278 (nyeri sedang) - 4,749 (nyeri sedang).
3. Pengaruh kompres hangat terhadap tingkat nyeri punggung ibu hamil trimester III di Puskesmas Sekernan Ilir tahun 2020.

Berdasarkan hasil penelitian Pengaruh kompres hangat terhadap tingkat nyeri punggung ibu hamil trimester III dapat dilihat pada tabel 3 berikut :

Tabel 3. Pengaruh Kompres Hangat Terhadap Tingkat Nyeri Punggung Ibu Hamil Trimester III Di Puskesmas Sekernan Ilir Tahun 2020

\begin{tabular}{lccccc}
\hline \multicolumn{1}{c}{ Variabel } & Mean & SD & SE & P & N \\
\hline $\begin{array}{l}\text { Nyeri Sebelum } \\
\text { diberikan Kompres }\end{array}$ & 5,9 & 0, & 0,1074 & & \\
$\begin{array}{l}\text { Hangat } \\
\begin{array}{l}\text { Nyeri Sesudah } \\
\text { diberikan Kompres }\end{array}\end{array}$ & 6,5 & 0, & 0,1150 & 0,000 & 30 \\
Hangat & & 6 & & & \\
\hline
\end{tabular}

Hasil analisis didapatkan rata-rata derajat nyeri sebelum diberi kompres hangat adalah 5,857 (nyeri sedang) dengan standar deviasi 0,5882. Pada pengukuran kedua (sesudah dilakukan kompres hangat) didapat rata-rata derajat nyeri 4,513 (nyeri sedang) dengan standar deviasi 0,6301. Terlihat nilai perbedaan rata-rata antara derajat nyeri pre-test dan post-test adalah 1,344 dengan standar deviasi 0,4599. Hasil uji statistik didapatkan nilai $p$-value 0,000 , maka dapat disimpulkan ada pengaruh kompres hangat terhadap tingkat nyeri punggung ibu hamil trimester III di Puskesmas Sekernan Ilir tahun 2020.

\section{Pembahasan}

1. Gambaran tingkat nyeri punggung ibu hamil trimester III sebelum diberikan kompres hangat di Puskesmas Sekernan Ilir tahun 2020. Berdasarkan hasil analisis didapatkan rata-rata derajat nyeri sebelum dilakukan kompres hangat adalah nyeri sedang. Dari hasil estimasi interval dapat disimpulkan bahwa 95\% diyakini derajat nyeri sebelum 
dilakukan kompres hangat adalah diantara 5,637- 5,607.

Nyeri punggung bawah merupakan nyeri punggung yang terjadipada area lumbo sakral. Nyeri punggung bawah biasanya akan meningkat intensitasnya seiring pertambahan usia kehamilan karena nyeri merupakan akibat pergeseran pusat grativasi wanita hamil dan postur tubuhnya. Perubahan-perubahan ini disebabkan oleh berat uterus yang membesar. Jika wanita hamil tidak memberikan perhatian penuh terhadap postur tubuh kebelakang akibat peningkatan lordosis. Lengkung ini kemudian akan meregangkan otot punggung dan menimbulkan rasa sakit atau nyeri (Varney, 2007:543).

Secara keseluruhan nyeri punggung merupakan keluhan yang paling banyak dijumpai dengan angka prevalensi mencapai 49\%, 80-90\% dari ibu hamil yang mengalami nyeri punggung menyatakan tidak melakukan usaha apapun untuk mengatasi timbulnya gejala tersebut, dengan kata lain hanya sekitar 10-20\% dari mereka yang melakukan perawatan medis ke tenaga kesehatan (Kreshnanda, 2016).

Berdasarkan penelitian Maria (2017) yang menyatakan bahwa usia kehamilan merupakan faktor risiko yang menyebabkan nyeri punggung, yaitu semakin tinggi usia kehamilan semakin besar risiko terjadinya nyeri punggung bawah. Penelitian lain telah menunjukkan bahwa prevalensi nyeri punggung bawah selama kehamilan meningkat seiring dengan usia kehamilan.

Nyeri punggung yang segera tidak diatasi, bisa mengakibatkan nyeri punggung jangka panjang, meningkatkan kecenderungan nyeri punggung pasca partum dan nyeri punggung kronis yang akan lebih sulit untuk diobati atau disembuhkan, yaitu ketika nyeri sampai menyebar kedaerah pelvis yang menyebabkan kesulitan berjalan sehingga memerlukan kruk ataupun alat bantu jalan lainnya. Nyeri punggung bawah dapat menimbulkan dampak negatif pada kualitas hidup ibu hamil karena terganggunya aktifitas fisik sehari-hari misalnya akan kesulitan menjalankan aktivitas seperti berdiri setelah duduk, berpindah dari tempat tidur, duduk terlalu lama, berdiri terlalu lama, membuka baju dan melepaskan baju, maupun mengangkat dan memindahkan benda-benda sekitar (Luthfiah, 2016:149).

2. Gambaran tingkat nyeri punggung ibu hamil trimester III sesudah diberikan kompres hangat di Puskesmas Sekernan Ilir tahun 2020.

Berdasarkan hasil analisis didapatkan ratarata derajat nyeri sesudah dilakukan kompres hangat adalah nyeri sedang. Dari hasil estimasi interval dapat disimpulkan bahwa $95 \%$ diyakini derajat sesudah dilakukan kompres hangat adalah diantara 4,278-4,749.

Seiring dengan pertambahan usia kehamilan, postur wanita berubah untuk mengkompensasi berat uterus yang sedang tumbuh. Bahu tertarik ke belakang sebagai akibat pembesaran abdomen yang menonjol, dan untuk mempertahankan keseimbangan tubuh, kelengkungan tulang belakang ke arah dalam menjadi berlebihan. Relaksasi sendi sakroiliaka, yang mengiringi perubahan postur, menyebabkan berbagai tingkat nyeri punggung setelah ketegangan yang berlebihan, keletihan, postur membungkuk atau mengangkat sesuatu ( Baiq \& Oky, $2018: 25$ ).

Penggunaan kompres hangat untuk area yang tegang dan nyeri dianggap mampu meredakan nyeri. Rasa hangat mengurangi spasme otot yang disebabkan oleh iksemia yang merangsang neuron yang memblok transmisi lanjut rangsang nyeri menyebabkan vasodilitas dan peningkatan aliran darah ke area yang dilakukan pengompresan. Area pengompresan berada di area lumbosacral, yaitu letaknya berada diatas tulang sacrum. Pada area lumbosacral memiliki peran utama yaitu menyangga berat badan (Tri 2018:5). 
Air hangat $\left(46,5-51,5^{0} \mathrm{C}\right)$ memiliki dampak fisiologis bagi tubuh, yaitu pelunakan jaringan fibrosa, mempengaruhi oksigenasi jaringan sehingga dapat mencegah kekakuan otot, memperlancar aliran darah, sehingga dapat menurunkan atau menghilangkan rasa nyeri. Hal ini dibuktikan pada penelitian Luthfiah (2016) yang menyebutkan kompres hangat dengan suhu $\left(46,5-51,5^{\circ} \mathrm{C}\right)$ menyebabkan 10 responden mengalami penurunan nyeri dengan rata-rata 2-3 point.

Kompres hangat selama kehamilan sangat bermanfaat bagi ibu hamil karena merupakan salah satu teknik mengurangi rasa nyeri nonfarmakologi yang dapat memberikan manfaat bagi ibu hamil, seperti memberikan ketenangan pada ibu hamil trimester III ditengah kondisi yang tidak nyaman dan terasa nyeri, sehingga ibu hamil memerlukan penanganan untuk mengurangi rasa tidak nyaman yang dirasakan ibu dalam proses kehamilan (Richard, $2017: 8$ ).

Penelitian ini menyatakan ada penurunan rata-rata nyeri punggung sesudah dilakukan kompres hangat yaitu sebesar 1,344. Hasil ini sejalan dengan penelitian yang dilakukan oleh Richard (2017) yang menyatakan bahwa nyeri punggung ibu hamil sebelum dan sesudah dilakukan kompres hangat pada 15 responden menunjukkan penurunan nyeri sebanyak 2,3. Berdasarkan hasil uji statistik diperoleh nilai $\mathrm{p}=0,000$ yang berarti ada pengaruh kompres hangat terhadap penurunan nyeri punggung ibu hamil trimester III di Puskesmas Pesantren I Kota Kediri.

\section{Pengaruh kompres hangat terhadap tingkat nyeri punggung ibu hamil trimester III di Puskesmas Sekernan Ilir tahun 2020.}

Berdasarkan hasil analisis didapatkan rata-rata derajat nyeri sebelum diberi kompres hangat adalah nyeri sedang, pada pengukuran kedua sesudah dilakukan kompres hangat didapat rata-rata derajat nyeri sedang, namun terlihat perbedaan nilai rata-rata antara derajat nyeri pre-test dan post-test. Hasil uji statistik didapatkan nilai $\mathrm{p}<0.05$, maka dapat disimpulkan ada pengaruh kompres hangat terhadap tingkat nyeri punggung ibu hamil trimester III di Puskesmas Sekernan Ilir tahun 2020.

Usia kehamilan yang semakin lama semakin bertambah menyebabkan perubahan tubuh secara bertahap (postur tubuh) dan cara berjalan berubah. Peningkatan distensi abdomen yang membuat panggul miring kedepan, penurunan tonus otot perut dan peningkatan berat badan pada akhir kehamilan membutuhkan penyesuaian tulang kurvatura spinalis. Kurva lumbosakrum normal harus semakin melengkung dan didaerah servikodorsal harus terbentuk kurvatura (fleksi anterior kepala berlebihan) untuk mempertahankan keseimbangan. Perubahan ini yang sering menimbulkan rasa tidak nyaman pada punggung ibu hamil (Dewi, dkk, 2014:14).

Trimester III perubahan postur ibu hamil akan tampak signifikan seiring dengan besarnya janin yang juga mengakibatkan perubahan lengkung lordosis pada lumbal. Distensi abdomen yang meningkat mempengaruhi pelvis untuk cenderung tilting ke depan. Sementara penurunan tonus otot abdominal membutuhkan penyesuaian ulang. Terjadinya pergeseran Center of Gravity (COG) ke depan mengakibatkan kurva lumbosacral semakin lordosis. Hal ini mempengaruhi servical untuk cenderung flexi ke anterior untuk mempertahankan keseimbangan. Hal ini sering meyebabkan nyeri punggung (Anggraini, 2018:1).

Nyeri punggung bawah sering terjadi selama kehamilan dan cenderung meningkat saat usia kehamilan meningkat. Dalam beberapa kasus, rasa sakit menjalar ke pantat, tungkai dan kaki. Bagi banyak wanita, rasa sakit bisa menjadi sangat parah sehingga mengganggu aktivitas sehari-hari dan mengganggu tidur. Di Amerika Serikat, 
wanita diajari bahwa nyeri punggung adalah bagian normal dari kehamilan. Intervensi yang telah digunakan hingga saat ini untuk membantu mengelola rasa sakit termasuk latihan, istirahat yang sering, kompres panas dan dingin, pijat, akupunktur, aromaterapi, relaksasi, yoga dan farmakologi ( Liddle \& Pennick, 2015:7).

Kompres hangat merupakan salah satu strategi non fermakologi untuk mengatasi nyeri punggung. Penggunaan kompres hangat sangat direkomendasikan untuk masalah nyeri punggung karena mudah dilakukan dan tidak mengeluarkan banyak biaya untuk melaksanakannya. Kompres hangat dapat memberikan rasa hangat untuk memenuhi kebutuhan rasa nyaman, mengurangi atau membebaskan nyeri, mengurangi atau mencegah spasme otot dan memberikan rasa hangat pada daerah tertentu (Tri 2018:6).

Perbedaan antara sebelum dan sesudah pemberian kompres hangat ini terjadi karena kompres hangat mempunyai dampak fisiologis yaitu dapat melunakkan jaringan fibrosa, membuat otot tubuh lebih rileks, menurunkan atau menghilangkan rasa nyeri, dan memperlancar aliran darah.

Rasa panas yang ditimbulkan dari kompres hangat dapat mengakibatkan dilatasi dan terjadi perubahan fisiologis sehingga dapat memperlancar peredaran darah dan meredakan nyeri. Respon panas inilah yang digunakan untuk terapi penurunan nyeri. Efek terapeutik pemberian kompres hangat akan dapat mengurangi kejang otot dan menurunkan kekakuan tulang sendi. Hal ini sejalan dengan penelitian Sulistyarini, dkk (2013) didapatkan ada perbedaan yang signifikan antara intensitas nyeri sebelum dan sesudah diberikan kompres hangat. Sebelum diberikan rata-rata inensitas nyeri yaitu 5,811 dan sesudah di berikan kompres hangat adalah 3,652. Sehingga kompres hangat yang dilakukan pada ibu hamil trimester III berpengaruh menurunkan intensitas nyeri punggung yang dirasakan ibu.

Efektifitas kompres hangat dengan air panas tidak hanya memberikan kenyamanan tapi juga meningkatkan sirkulasi pada ibu hamil sehingga dapat mencegah potensial terjadinya panas dalam perut. Sirkulasi peredaran darah yang baik akan meminimalkan terjadinya kontraksi perut dan kram kaki. Kontraksi perut yang dimaksudkan adalah Braxton-Hicks atau kontraksi palsu (Sulistyarini, dkk, 2013:9).

Selama penelitian ini dilakukan, responden yang sudah diberikan terapi kompres hangat mengekspresikan rasa nyaman melalui ketenangan dan penurunan skala nyeri. Metode praktis yang diberikan dalam pelaksanaan nyeri secara mandiri dirumah diantaranya dapat dengan menggunakan sarana hangat lain, seperti mandi air hangat, kompres hangat atau obat gosok hangat.

Pengaruh kompres hangat dapat menurunkan nyeri punggung ibu hamil dibuktikan dalam penelitian Dewi, dkk (2014) di Desa Talangsuko Kota Malang, menunjukkan responden yang mengalami nyeri punggung sebelum intervensi, sebagian besar pada rentang kategori nyeri ringan $54,5 \%$ dan sebagian kecil pada rentang kategori nyeri sedang $45,5 \%$. Setelah di intervensi, didapatkan bahwa sebagian besar berada pada rentang kategori nyeri ringan yaitu $54,5 \%$ dan sebagian kecil pada rentang kategori tidak nyeri yaitu $45,5 \%$. Hal ini menunjukkan bahwa ada pengaruh pemberian kompres air hangat terhadap intensitas nyeri punggung yang dialami oleh ibu hamil trimester III.

Hasil penelitian ini juga sejalan dengan yang dilakukan oleh Tri (2018) di Klinik Pelita Hati Banguntapan bantul didapatkan ada perbedaan yang signifikan antara intensitas nyeri sebelum dan sesudah diberikan kompres hangat. Penurunan skala nyeri setelah diberikan kompres hangat adalah 3,30 yaitu sebelum diberikan ratarata inensitas nyeri yaitu 7,35 (Nyeri berat) 
dan sesudah di berikan kompres hangat adalah 4,05 (Nyeri Sedang). Sehingga kompres hangat yang dilakukan pada ibu hamil trimester III berpengaruh menurunkan intensitas nyeri punggung yang dirasakan ibu.

Penelitian ini bertentang dengan penelitian yang dilakukan oleh Baiq \& Oky (2018), yang menyatakan bahwa massage endorphin lebih efektif dibandingkan dengan perlakuan kompres hangat dalam menurunkan nyeri punggung ibu hamil TM III, karena metode kompres hangat akan lebih efektif apabila pada saat pemberian kompres hangat dapat digabungkan dengan metode lainnya dalam menurunkan nyeri punggung ibu hamil.

\section{SIMPULAN}

Berdasarkanhasildanpembahasanpen elitiantentang Pengaruh kompres hangat terhadap tingkat nyeri punggung ibu hamil trimester III di Puskesmas Sekernan Ilir tahun 2020 dapatdisimpulkansebagai berikut : Hasil analisis sebelum diberikan kompres hangat rata-rata derajat nyeri adalah 5,857 (nyeri sedang). Hasil analisis sesudah diberikan kompres hangat rata-rata derajat nyeri adalah 4, 513 (nyeri sedang). Hasil analisis ada pengaruh kompres hangat terhadap tingkat nyeri punggung ibu hamil trimester III dan diperoleh $p$-value $=0.000$ $(\mathrm{p}<0.05)$.

\section{SARAN}

Bagi Puskesmas Sekernan Ilir Diharapkan bagi Puskesmas untuk Memberikan pengetahuan pada ibu hamil tentang cara untuk mengurangi nyeri punggung ibu hamil trimester III, dengan pengobatan non farmakologi yaitu kompres hangat menggunakan air dengan suhu $46,5-51,5^{\circ} \mathrm{C}$ lalu di kompres ke area yang tegang dan nyeri yaitu punggung ibu hamil. Mengajarkan teknik kompres hangat untuk mengurangi nyeri punggung ibu hamil trimester III sehingga dapat diterapkan dirumah ibu masing-masing.
Bagi Peneliti Selanjutnya Diharapkan dapat dipergunakan sebagai bahan masukan untuk pengembangan penelitian tentang masalah yang sama pada tempat yang berbeda dan variabel yang berbeda khususnya tentang nyeri punggung ibu hamil trimester III.

\section{DAFTAR PUSTAKA}

Ambarwati, 2009. Asuhan Kebidanan Komunitas. Nuha Medika. Yogyakarta

Andina \& Yuni, 2017. Asuhan Pada kehamilan. Pustaka Baru Press. Yogyakarta

Anggraini, 2018. Penerapan Kompres Hangat dan Pijat Punggung (Massage) Untuk Mengurangi Nyeri Punggung Pada Ibu Hamil Trimester III. Gombong : Sekolah Tinggi Ilmu Kesehatan Muhammadiyah

Ardiana, 2016. Beda pengaruh Antara Senam hamil Dengan Kompres Hangat Dan Massage Terhadap Penurunan Nyeri Punggung Bawah Pada Ibu Hamil Trimester III. Surakarta : Universitas Muhammadiyah

Aulia dkk, 2018. Pengaruh Kompres Air Hangat dan Air Dingin Terhadap Nyeri Tulang Belakang Ibu Hamil Trimester III di Wilayah Kerja Puskesmas Rajapolah Tahun 2018. Jawa Barat : Poltekkes Kemenkes Tasikmalaya

Baik \& Oky, 2018. Perbedaan Efektifitas Endorphin Massage Dengan Kompres Hangat Terhadap Penurunan Nyeri Punggungibu Hamil Trimester Iii Di Puskesmas Wilayah Kerja Sekota Mataram. Jurnal Kesehatan Prima

Dinkes Kabupaten Muaro Jambi, 2018.Profil Dinas Kesehatan Dinkes Kabupaten Muaro Jambi tahun 2018. 
2019. Profil Dinas Kesehatan Dinkes Kabupaten Muaro Jambi tahun 2019.

Dewi, dkk, 2014. Pengaruh Pemberian Kompres Air Hangat Terhadap Intensitas Nyeri Punggung Ibu Hamil Trimester III. Malang : Akbid Wijaya Kusuma

Hidayat, A.A 2012. Metode Penelitian Kebidanan Dan Teknik Analisis Data. Penerbit Salemba Medika.Jakarta

Kreshnanda, 2016. Prevalensi Dan Gambaran Keluhan Low Back Pain Pada Wanita di Pasar Bandung. Bandung : Kedokteran Universitas Udayana

Liddle \& Pennick, 2015. Interventions For Preventing And Treating Low-Back And Pelvic Pain During Pregnancy (Review) . Cochrane Library

Luthfiah, 2016. Perbedaan Masase Effleurage dan Kompres Hangat Terhadap Penurunan Nyeri Punggung Pada Ibu Hamil Trimester III. Mojokerto : Akper Dian Husada

Manuaba, 2010.Ilmu Kandungan.Nuha Medika. EGC Jakarta

Maria, 2017. Jurnal Of Low Back Pain During Pregnancy. Revista Brasileira De Anestesiologia

Maternity, dkk, 2016. Asuhan Kebidanan Kehamilan. Bina Rupa Aksara. yogyakarta

Mohamad, dkk, 2012.Teori Pengukuran Nyeri. Nuha Medika. Yogyakarta.

Notoatmodjo, 2010. Metodologi Penelitian Kesehatan. Rineka Cipta. Jakarta

Prawirohardjo, 2009. Ilmu Kandungan.PT. Bina Pustaka Sarwnono Prawirohardjo. Jakarta

Puskesmas Puskesmas Sekernan Ilir, 2019. Laporan Tahunan KIA Puskesmas Sekernan Ilir Kabupaten Muaro Jambi

Richard, 2017. Teknik Effleurage Dan Kompres Hangat Efektif Menurunkan Nyeri Punggung Ibu Hamil. Kediri : STIKES Rs. Baptis Kediri.
Sugiono, 2010. Memahami Penelitian Kualitatif. Alfabeta. Bandung

Sulistyarini, dkk, 2013. Kompres Hangat Dan Gosok Punggung (Backrub) Efektif Menurunkan Nyeri Punggung Ibu Hamil Trimester III. Kediri : STIKES RS. Baptis

Sutanto, dkk, 2019. Asuhan Pada kehamilan. Pustaka Baru Press. Yogyakarta

Tri, 2018. Pengaruh Kompres Hangat Terhadap Intensitas Nyeri Punggung Pada Ibu hamil Trimester III di Klinik Pelita hati Banguntapan Bantul. Yogyakarta : Universitas Aisyiyah

Tyastuti \& Heni, 2016. Asuhan Kebidanan Kehamilan. Kementrian Kesehatan Republik Indonesia. Jakarta : $168 \mathrm{hlm}$

Walyani, 2017. Asuhan Kebidanan Pada Kehamilan. Pustaka Baru Press. Yogyakarta

Wirawan, 2017. Intensitas Nyeri (Numeric Rating Scale) Pada Penderita Kanker Payudara Di Rumah Sakit Universitas Hasanuddin. Makassar : Universitas Hasanuddin. 